\title{
DETERMINAN KINERJA PEGAWAI PADA BADAN KEPEGAWAIAN DAN PENGEMBANGAN SUMBER DAYA MANUSIA DAERAH KABUPATEN KERINCI
}

\author{
Herry Irawan, SE ${ }^{1}$, Dr. H. Elfiswandi, SE.,MM.,Ak.,CA ${ }^{2}$ \\ ${ }^{\mathbf{1}}$ Fakultas Ekonomi dan Bisnis Universitas Putra Indonesia "YPTK" Padang \\ e-mail : irawanherry704@gmail.com \\ ${ }^{2}$ Fakultas Ekonomi dan Bisnis Universitas Putra Indonesia "YPTK" Padang \\ e-mail : elfiswandi@upiyptk.ac.id
}

\begin{abstract}
Human resources $(H R)$ is one of the most important factors that cannot be separated from an organization, both an institution or a company. The government in carrying out its duties and responsibilities are required to produce good performance. This study aims to determine the effect of organizational commitment, work environment and work discipline on employee performance. The sample used in this study were 95 respondents who were in the Kerinci Regency BKPSDMD. The analytical method used in this study is multiple linear regression analysis. The results of this study indicate that organizational commitment and significant effect on employee performance, work environment influences and significantly affects employee performance, work discipline has a significant effect on employee performance, organizational commitment, work environment and work discipline jointly influences and significantly affects employee performance Kerinci Regency BKPSDMD.
\end{abstract}

Keywords: Organizational Commitment, Work Environment, Work Discipline, Employee Performance

\begin{abstract}
ABSTRAK
Sumber daya manusia (SDM) adalah salah satu faktor yang sangat penting bahkan tidak dapat dilepaskan dari sebuah organisasi, baik institusi maupun perusahaan. Pemerintah dalam melaksanakan tugas dan tanggung jawabnya dituntut untuk menghasilkan kinerja yang baik. Penelitian ini bertujuan untuk mengetahui pengaruh komitmen organisasi, lingkungan kerja dan disiplin kerja terhadap kinerja pegawai. Sampel yang digunakan dalam penelitian ini sebanyak 95 orang responden yang berada pada BKPSDMD Kabupaten Kerinci. Metode analisis yang digunakan dalam penelitian ini adalah analisis regresi linier berganda. Hasil penelitian ini menunjukkan bahwa komitmen organisasi berpengaruh dan signifikan terhadap kinerja pegawai, lingkungan kerja berpengaruh dan signifikan terhadap kinerja pegawai, disiplin kerja berpengaruh signifikan terhadap kinerja pegawai, komitmen organisasi, lingkungan kerja dan disiplin kerja secara bersama-sama berpengaruh dan signifikan terhadap kinerja pegawai BKPSDMD Kabupaten Kerinci.
\end{abstract}

Kata Kunci : Komitmen Organisasi, Lingkungan Kerja, Disiplin Kerja, Kinerja Pegawai 


\section{PENDAHULUAN}

Keberhasilan suatu organisasi sangat tergantung pada sumber daya manusianya, seberapa bagus program-program yang dibuat, tidak ada artinya tanpa sumber daya yang berkualitas yang mengukir prestasi tinggi dalam setiap pelaksanaan kegiatan dan tugas yang diberikan kepadanya. Untuk memperoleh sumber daya yang berkualitas tentu dibutuhkan lingkungan kerja yang nyaman dan kondusif, dengan lingkungan kerja yang menyenangkan setiap pegawai dapat bekerja dengan baik dan menyelesaikan tugasnya dengan kinerja yang tinggi.

Kinerja pegawai suatu organisasi merupakan salah satu isu yang banyak menarik perhatian peneliti dan akademisi beberapa tahun terakhir. Berbagai studi yang dilakukan secara khusus mengidentifikasi faktor determinan kinerja pegawai telah memberikan banyak informasi yang menarik untuk meningkatkan kinerja karyawan, yang pada akhirnya berdampak terhadap kinerja oganisasi secara keseluruhan, tak terkecuali di organisasi pemerintahan. Meski demikian, karena kompleksitas masalah yang dihadapi oleh organisasi dalam upaya meningkatkan kinerja pegawainya berakhir dengan gagal atau tidak memenuhi harapan maksimal. Dalam organisasi pemerintahan di Indonesia misalnya, upaya untuk meningkatkan kinerja pegawai negeri sipil dilakukan dengan berbagai cara, dan salah satunya adalah dengan memberikan remunasi atau tunjangan khusus untuk meningkatkan motivasi kerja pegawai.

Kinerja merupakan istilah yang berasal dari kata job performance atau actual performance (prestasi kerja atau prestasi sesungguhnya yang dicapai seseorang). Terdapat dua faktor yang mempengaruhi kinerja karyawan yaitu faktor dalam diri pegawai dan faktor pekerjaanya. Faktor yang ada pada diri pegawai yaitu kecerdasan (IQ), kecakapan khusus, umur, jenis kelamin, masa kerja, kepribadian, emosi, cara berfikir, persepsi dan sikap kerja. Kinerja adalah hasil kerja secara kualitas dan kuantitas yang dicapai oleh seorang pegawai dalam melaksanakan tugasnya sesuai dengan tanggung jawab yang diberikan kepadanya (Mangkunegara, 2016:67).

Komitmen organisasi merupakan dimensi perilaku penting yang dapat digunakan untuk menilai kecenderungan karyawan untuk bertahan sebagai anggota organisasi. Komitmen merupakan identifikasi dan keterkaitan seseorang yang relatif kuat terhadap organisasi. Karyawan dengan komitmen yang tinggi memiliki perbedaan sikap dibanding yang berkomitmen rendah. Komitmen organisasi yang tinggi menghasilkan performa kerja, rendahnya tingkat absen dan rendahnya tingkat keluar-masuk (turnover) karyawan. Komitmen yang timggi menjadikan individual peduli dengan nasib organisasi dan berusaha menjadikan organisasi ke arah yang lebih baik (Sapitri, 2016:2).

Lingkungan kerja merupakan lingkungan dimana para pegawai tersebut bekerja. Lingkungan kerja bagi para pegawai akan mempunyai pengaruh yang tidak kecil terhadap jalannya operasi instansi. Lingkungan kerja akan mempengaruhi para pegawai sehingga langsung maupun tidak langsung akan dapat mempengaruhi produktifitas instansi (Budianto \& Katini, 2015:101).

Keberadaan disiplin kerja sangat diperlukan dalam suatu organisasi karena dalam suasana disiplinlah organisasi akan dapat melaksanakan program-program kerjanya untuk mencapai sasaran yang telah ditetapkan. Pegawai yamg diplin dan tertib menaati semua norma-norma dan perturan yang berlaku dalam organisasi akan dapat meningkatkan efisiensi, efektivitas, dan produktivitas.

Disiplin merupakan tindakan manajemen untuk mendorong para karyawan mematuhi tuntutan berbagai ketentuan tersebut dengan kata lain pendisiplinan karyawan adalah suatu bentuk pelatihan yang berusaha memperbaiki dan membentuk pengetahuan sikap dan perilaku para karyawan sehingga karyawan tersebut secara sukarela kooperatif dengan 
karyawan yang lain dalam meningkatkan prestasi kerja. Disiplin diartikan sebagai sistem yang berisi kebijakn peraturan, prosedur yang mengatur perilaku baik secara individu maupun kelompok dalam sistem organisasi (Meilany dan Ibrahim, 2015:2).

\section{METODOLOGI PENELITIAN}

\subsection{Objek Penelitian}

Penelitian ini dilakukan di badan kepegawaian dan pengembangan sumber daya manusia daerah (BKPSDMD) Kabupaten Kerinci. Waktu penelitian ini dilaksanakan pada bulan Desember 2019, namun beberapa persiapan telah dilakukan sebelumnya. Hal ini didasarkan berbagai faktor untuk memperlancar pengumpulan data dalam penelitian, seperti kemudahan pengambalian data dan menghemat waktu serta tenaga yang digunakan.

\subsection{Variabel Operasional}

Pada penelitian ini penulis menggunakan dua variabel yaitu:

- Variabel independen (bebas)

Variabel bebas adalah merupakan variabel yang mempengaruhi atau yang menjadi sebab perubahannya atau timbulnya variabel dependen atau terikat (Sugiyono, 2014, hal 59). Dalam penelitian ini yang menjadi variabel bebas (independent variable) adalah Komitmen Organisasional ( $\left.\mathrm{X}_{1}\right)$, Lingkungan Kerja $\left(\mathrm{X}_{2}\right)$, Disiplin Kerja $\left(\mathrm{X}_{3}\right)$.

- Variabel dependen (terikat)

Variabel terikat merupakan variabel yang dipengaruhi atau yang menjadi akibat, karena adanya variabel bebas (Sugiyono, 2014, hal 59). Dalam penelitian ini yang menjadi variabel terikat (dependent variable) adalah Kinerja Pegawai (Y).

\subsection{Analisis Regresi Linier Berganda}

Analisis regresi linier berganda digunakan untuk memprediksikan berubahnya nilai variabel tertentu bila variabel lain berubah. Menurut Sugiyono (2014, hal 277), dikatakan regresi berganda karena jumlah variabel independennya lebih dari satu. Analisis regresi berganda dapat dilakukan apabila terdapat minimal 2 variabel independen. Dalam pengujian hipotesis penelitian, digunakan uji regresi linier berganda.

Adapun tujuan menggunakan analisa regresi berganda dalam penelitian ini adalah untuk mengetahui bagaimana pengaruh variabel bebas disiplin kerja, empowerment dan kepuasan kerja secara simultan (bersama-sama) terhadap kinerja pegawai BKPSDMD Kabupaten Kerinci. Dengan demikian, dapat dikemukakan persamaan regresi linear berganda dalam penelitian ini adalah sebagai berikut :

Keterangan :

$$
\mathbf{Y}=\mathbf{a}+\mathbf{b}_{1} \mathbf{X}_{1}+\mathbf{b}_{2} \mathbf{X}_{2}+\mathbf{b}_{3} \mathbf{X}_{3}+e
$$

$$
\begin{array}{ll}
\mathrm{Y} & =\text { Kinerja pegawai } \\
\mathrm{a} & =\text { Konstanta } \\
\mathrm{b} & =\text { Koefisien regresi } \\
\mathrm{X}_{1} & =\text { Komitmen organisasional } \\
\mathrm{X}_{2} & =\text { Lingkungan kerja } \\
\mathrm{X}_{3} & =\text { Disiplin kerja } \\
\mathrm{e} & =\text { error }
\end{array}
$$

\section{Uji Parsial (Uji-t)}

Uji statistik $\mathrm{t}$ digunakan untuk menunjukkan seberapa jauh pengaruh satu variabel independen terhadap variabel dependen dengan menganggap variabel independen lainnya konstan (Ghozali, 2017, p. 96). 


\section{Uji Simultan (Uji-F)}

Uji statistik F pada dasarnya menunjukkan apakah semua variabel independen yang dimasukkan dalam model mempunyai pengaruh secara bersama-sama atau simultan terhadap variabel dependen (Ghozali, 2017, p. 96).

\section{Uji Koefisien Determinasi (R-Square/ $\mathbf{R}^{\mathbf{2}}$ )}

Koefisien determinasi $\left(\mathrm{R}^{2}\right)$ digunakan untuk mengukur seberapa jauh kemampuan model dalam menerangkan variasi variabel dependen. Nilai koefisien determinasi adalah antara nol dan satu. Nilai $\mathrm{R}^{2}$ yang kecil berarti kemampuan variabel independen dalam menjelaskan variabel dependen yang terbatas.

\section{HASIL DAN PEMBAHASAN}

Kuesioner disebarkan kepada pegawai Badan Kepegawaian dan Pengembangan Sumber Daya Manusia Daerah Kabupaten Kerinci sebanyak 95 buah dan semua kuesioner berhasil dikumpulkan kembali. Penyebaran kuesioner ini dilakukan dari tanggal 22 Januari 2020 sampai dengan 29 Januari 2020.

\section{Uji Normalitas}

Uji normalitas bertujuan untuk menguji bahwa distribusi sampel dari data mendekati normalitas populasi. Pengujian normalitas dilakukan dengan menggunakan analisa grafik histogram dan grafik p-plot. Data dapat dikatakan berdistribusi normal jika data menyebar disekitar garis diagonal dan mengikuti arah garis diagonal atau grafik histogramnya, sebaliknya data dikatakan tidak berdistribusi normal, jika data menyebar jauh dari arah garis atau tidak mengikuti diagonal atau grafik histogramnya. Hasil uji normalitas dapat dilihat pada gambar di bawah ini :

\section{Gambar 4.1 Grafik Histogram}

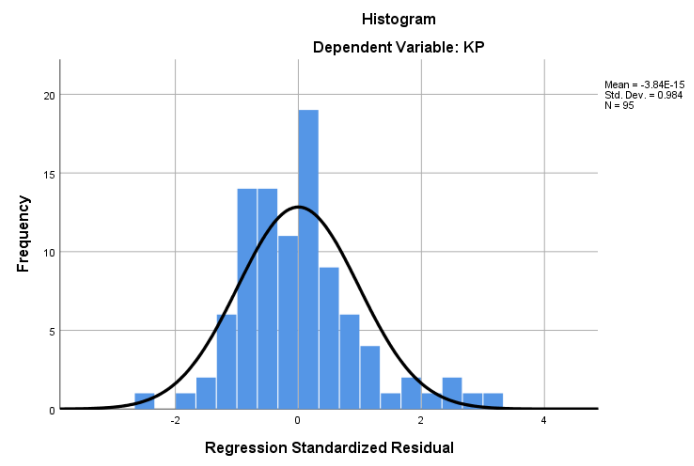

Sumber : Lampiran Print out SPSS

\section{Gambar 4.2 Grafik Normal P-P Plot}

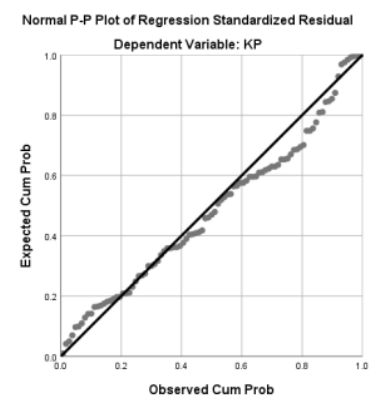

Sumber : Lampiran Print out SPSS 
Berdasarkan gambar di atas dapat dilihat bahwa grafik histogram dan grafik p-plot memberikan pola distribusi yang bergerak ke arah kanan dan titik-titik menyebar mengikuti dan mendekati garis diagonal sehingga dapat disimpulkan bahwa model regresi memenuhi asumsi normalitas.

\section{Uji Multikolinearitas}

Salah satu syarat dalam pemakaian analisis regresi linier berganda adalah terlebih dahulu harus dilakukan uji multikolinieritas dimana sesama variabel bebas $\left(\mathrm{X}_{1}, \mathrm{X}_{2}\right.$ dan $\left.\mathrm{X}_{3}\right)$ tidak boleh berhubungan signifikan. Apabila sesama variabel bebas terdapat hubungan yang signifikan, maka salah satu variabel bebas tersebut tidak dimasukkan ke dalam regresi linier berganda.

\section{Tabel 4.2 Hasil Uji Multikolinearitas}

\begin{tabular}{llrr} 
& \multicolumn{3}{c}{ Collinearity Statistics } \\
Model & Tolerance & VIF \\
\hline 1 (Constant) & & \\
KEP & .691 & 1.446 \\
KOM & .604 & 1.657 \\
DIS & .727 & 1.375 \\
\hline
\end{tabular}

Sumber : Data diolah peneliti, 2020

Dari tabel di atas dapat diketahui nilai VIF 1,446 untuk $\mathrm{X}_{1}$ (komitmen organisasi), nilai VIF 1,657 untuk $\mathrm{X}_{2}$ (lingkungan kerja), dan nilai VIF 1,375 untuk $\mathrm{X}_{3}$ (disiplin kerja). Karena keseluruhan nilai lebih rendah dari 10 sehingga dapat disimpulkan tidak terjadi multikolinearitas, Dengan demikian semua variabel bebas yang diteliti dapat memenuhi syarat pemakaian model regresi berganda.

\section{Uji Heteroskedastisitas}

Hasil pengujian heteroskedastisitas untuk masing-masing variabel kepemimpinan, kompetensi, disiplin kerja dan kinerja pegawai dapat dilihat pada gambar di bawah ini :

\section{Gambar 4.3 Hasil Uji Heteroskedastisitas}

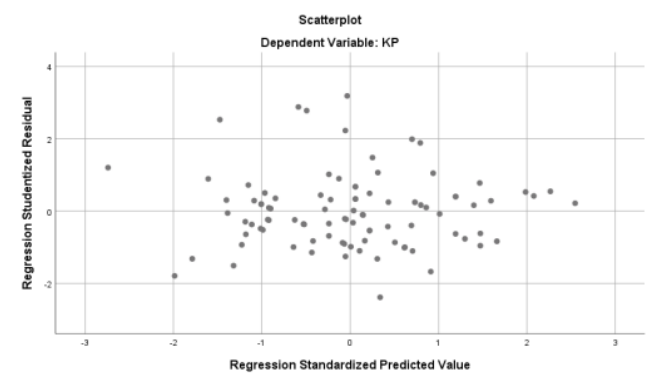

Sumber : Data diolah peneliti, 2020

Berdasarkan tampilan scatterplot, terlihat bahwa plot menyebar secara acak di atas maupun di bawah angka nol (0) pada sumbu regression studentized residual, maka dapat disimpulkan bahwa uji heteroskedastisitas menggunakan metode analisis grafik, pada model regresi yang terbentuk dinyatakan tidak terjadi heteroskedastisitas.

\section{Analisis Regresi Linier Berganda}

Analisis regresi linier berganda digunakan untuk memprediksikan berubahnya nilai variabel tertentu bila variabel lain berubah. Tujuan menggunakan regresi linier berganda adalah untuk mengetahui dan menjelaskan pengaruh komitmen organisasi, lingkungan kerja 
dan disiplin kerja secara bersama-sama terhadap kinerja pegawai. Persamaan analisis regresi linier berganda yang digunakan dalam penelitian ini adalah sebagai berikut :

Tabel 4.3 Hasil Regresi Linier Berganda

\begin{tabular}{lrrrr}
\hline \multicolumn{5}{c}{ Unstandardized Coefficients } \\
\multicolumn{1}{c}{ Model } & \multicolumn{1}{c}{ B } & Std. Error & \multicolumn{1}{c}{ t } & Sig. \\
\hline 1 (Constant) & 6.259 & 4.253 & 1.472 & .145 \\
KO & .314 & .110 & 2.861 & .005 \\
LK & .314 & .094 & 3.341 & .001 \\
DK & .336 & .068 & 4.973 & .000 \\
\hline
\end{tabular}

Sumber : Data diolah peneliti, 2020

Berdasarkan perhitungan diperoleh nilai koefisien regresi komitmen organisasi $\left(\mathrm{X}_{1}\right)$ sebesar 0,314, nilai koefisien regresi lingkungan kerja $\left(\mathrm{X}_{2}\right)$ sebesar 0,314 , nilai koefisien regresi disiplin kerja $\left(\mathrm{X}_{3}\right)$ sebesar 0,336. Berdasarkan angka tersebut maka dapat disusun persamaan garis regresi sebagai berikut :

$$
\mathrm{KP}=6,259+0,314 \mathrm{KO}+0,314 \mathrm{LK}+0,336 \mathrm{DK}
$$

\section{Uji Parsial (Uji-t)}

Uji statistik $\mathrm{t}$ digunakan untuk menunjukkan seberapa jauh pengaruh satu variabel independen terhadap variabel dependen dengan menganggap variabel independen lainnya konstan. Berdasarkan tabel 4.3 diatas maka dapat ditarik kesimpulan bahwa :

1. Pengaruh komitmen organisasi dengan nilai $t$ hitung 2,861 lebih besar dari $t$ tabel $(\mathrm{df}=$ $\mathrm{n}-\mathrm{k}$ atau $\mathrm{df}=95-3=92$ nilai $\mathrm{t}$ tabel $=1,985$ ). Dari nilai signifkansi, diperoleh nilai sebesar 0,005 sedangkan tingkat toleransi kesalahan yang digunakan adalah sebesar 5\%. Sehingga dapat disimpulkan bahwa nilai signifikansi kecil dari 0,05. Berarti keputusannya adalah Ho ditolak dan Ha diterima, yang artinya komitmen organisasi berpengaruh dan signifikan terhadap kinerja pegawai pada Badan Kepegawaian dan Pengembangan Sumber Daya Manusia Daerah Kabupaten Kerinci.

2. Pengaruh lingkungan kerja dengan nilai $t$ hitung 3,341 lebih besar dari $t$ tabel $(\mathrm{df}=\mathrm{n}-\mathrm{k}$ atau $\mathrm{df}=95-3=92$ nilai $\mathrm{t}$ tabel $=1,985$ ). Dari nilai signifkansi, diperoleh nilai sebesar 0,001 sedangkan tingkat toleransi kesalahan yang digunakan adalah sebesar $5 \%$. Sehingga dapat disimpulkan bahwa nilai signifikansi kecil dari 0,05. Berarti keputusannya adalah Ho ditolak dan Ha diterima, yang artinya lingkungan kerja berpengaruh dan signifikan terhadap kinerja pegawai pada Badan Kepegawaian dan Pengembangan Sumber Daya Manusia Daerah Kabupaten Kerinci.

3. Pengaruh disiplin kerja dengan nilai $t$ hitung 4,973 lebih besar dari $t$ tabel $(\mathrm{df}=\mathrm{n}-\mathrm{k}$ atau $\mathrm{df}=95-3=92$ nilai $t$ tabel $=1,985$ ). Dari nilai signifkansi, diperoleh nilai sebesar 0,000 sedangkan tingkat toleransi kesalahan yang digunakan adalah sebesar $5 \%$. Sehingga dapat disimpulkan bahwa nilai signifikansi kecil dari 0,05. Berarti keputusannya adalah Ho ditolak dan Ha diterima, yang artinya disiplin kerja berpengaruh dan signifikan terhadap kinerja pegawai pada Badan Kepegawaian dan Pengembangan Sumber Daya Manusia Daerah Kabupaten Kerinci.

\section{Uji Simultan (Uji-F)}

Untuk mendapatkan bukti empiris ada atau tidaknya pengaruh nyata antara variabel yang terdiri dari komitmen organisasi, lingkungan kerja dan disiplin kerja secara bersama- 
sama terhadap kinerja pegawai, maka dilakukan F-test. Berdasarkan hasil pengujian diperoleh ringkasan hasil seperti yang terlihat pada tabel di bawah ini :

Tabel 4.4 Hasil Uji Simultan

\begin{tabular}{lrrrrr}
\hline Model & Sum of Squares & df & Mean Square & F & Sig. \\
\hline 1 Regression & 1063.161 & 3 & 354.387 & 40.372 & $.000^{\mathrm{b}}$ \\
Residual & 798.797 & 91 & 8.778 & & \\
Total & 1861.958 & 94 & & & \\
\hline Sumber : Data diolah peneliti, 2020 & & &
\end{tabular}

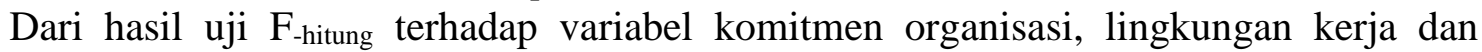
disiplin kerja dilakukan dengan program SPSS diperoleh nilai signifikan sebesar 0.000, sedangkan tingkat toleransi yang digunakan adalah sebesar 5\%. Atau dengan nilai $\mathrm{F}$-hitung sebesar 40,372 > F-tabel sebesar 2,70 $(\mathrm{dF} 1=3 \mathrm{dF} 2=95-3-1=91)$. Sehingga dapat disimpulkan bahwa nilai signifikansi kecil dari 0,05 . Berarti keputusannya adalah Ho ditolak dan $\mathrm{Ha}$ diterima, yang artinya variabel komitmen organisasi, lingkungan kerja dan disiplin kerja secara bersama-sama berpengaruh positif dan signifikan terhadap kinerja pegawai pada Badan Kepegawaian dan Pengembangan Sumber Daya Manusia Daerah Kabupaten Kerinci.

\section{Uji Koefisien Determinasi (R-Square)}

Berdasarkan hasil dari data yang telah diproses dapat dilihat kontribusi variabel kepemimpinan, kompetensi dan disiplin kerja terhadap kinerja pegawai. Berdasarkan hasil pengujian diperoleh ringkasan hasil seperti yang terlihat pada tabel di bawah ini :

\section{Tabel 4.5 Hasil Uji Koefisien Determinasi}

\begin{tabular}{lrrrr}
\hline & & & \multicolumn{2}{c}{ Durbin-Watson } \\
Model & R & R Square & Adjusted R Square & \\
\hline \multicolumn{1}{l}{$.756^{\mathrm{a}}$} & .571 & .557 & 2.017 \\
\hline Sumber : & Data diolah peneliti, 2020 & &
\end{tabular}

Dari tabel di atas diketahui komitmen organisasi, lingkungan kerja dan disiplin kerja, terhadap kinerja pegawai dengan nilai korelasi kuat terlihat dari nilai koefisien sebesar $(\mathrm{R})$ 0,571. Hasil adjusted $\mathrm{R}^{2}$ diperoleh nilai koefisien sebesar 0,557 atau 55,7\%. Artinya adalah komitmen organisasi, lingkungan kerja dan disiplin kerja proporsinya secara simultan menjelaskan pengaruh terhadap kinerja pegawai sebesar 55,70\%, sedangkan sisanya sebesar $44,3 \%$, dijelaskan oleh variabel lain yang tidak digunakan dalam penelitian ini.

\section{Pembahasan}

\section{Pengaruh Komitmen Organisasi terhadap Kinerja Pegawai}

Berdasarkan hasil analisis terdapat pengaruh dan signifikan antara komitmen organisasi terhadap kinerja pegawai pada Badan Kepegawaian dan Pengembangan Sumber Daya Manusia Daerah Kabupaten Kerinci. Hal ini dibuktikan dengan nilai $t$ hitung 2,861 lebih besar dari $t$ tabel $(2,861>1,985)$ dengan tingkat signifikan lebih kecil dari alpha $(0,005<0,05)$, maka Ho ditolak dan $\mathrm{H}_{\mathrm{a}}$ diterima. Artinya, secara parsial ada pengaruh dan signifikan antara komitmen organisasi $\left(\mathrm{X}_{1}\right)$ terhadap kinerja pegawai $(\mathrm{Y})$. Nilai koefisien regresi variabel komitmen organisasi bernilai positif sebesar 0,314. Artinya bahwa setiap peningkatan komitmen organisasi sebesar 1 satuan maka kinerja pegawai akan meningkat sebesar 0,314 satuan dengan asumsi variabel lain nilainya konstan.

Dalam dunia kerja komitmen karyawan memiliki pengaruh yang sangat penting, bahkan ada beberapa organisasi yang berani memasukkan unsur komitmen sebagai salah satu syarat untuk memegang jabatan/posisi yang ditawarkan dalam iklan lowongan kerja. Namun 
demikian, tidak jarang pengusaha maupun pegawai masih belum memahami arti komitmen secara sungguh-sungguh. Padahal pemahaman tersebut sangat penting bagi organisasi agar tercipta kondisi kerja yang kondusif, sehingga organisasi dapat berjalan secara efektif dan efisien.

Hasil penelitian ini sejalan dengan (Akbar, Musadieq \& Mukzam, 2017), (Pratam \& Dihan, 2017), (Malik, 2015), (Respatiningsih, 2015), (Putra, 2015). Hasil penelitiannya diperoleh bahwa komitmen organisasi berpengaruh dan signifikan baik secara parsial maupun secara simultan terhadap kinerja pegawai.

\section{Pengaruh Lingkungan Kerja terhadap Kinerja Pegawai}

Berdasarkan hasil analisis terdapat pengaruh dan signifikan antara lingkungan kerja terhadap kinerja pegawai pada Badan Kepegawaian dan Pengembangan Sumber Daya Manusia Daerah Kabupaten Kerinci. Hal ini dibuktikan dengan nilai $t$ hitung 3,341 lebih besar dari $t$ tabel $(3,341>1,985)$ dengan tingkat signifikan lebih kecil dari alpha $(0,001<0,05)$, maka Ho ditolak dan $\mathrm{H}_{\mathrm{a}}$ diterima. Artinya, secara parsial ada pengaruh dan signifikan antara lingkungan kerja $\left(\mathrm{X}_{2}\right)$ terhadap kinerja pegawai $(\mathrm{Y})$. Nilai koefisien regresi variabel lingkungn kerja bernilai positif sebesar 0,314. Artinya bahwa setiap peningkatan lingkungan kerja sebesar 1 satuan maka kinerja pegawai akan meningkat sebesar 0,314 satuan dengan asumsi variabel lain nilainya konstan.

Lingkungan kerja sangatlah perlu untuk diperhatikan karena merupakan salah satu faktor yang penting dalam menentukan kinerja pegawai. Hal ini dikarenakan mereka merasa tidak nyaman dalam bekerja sehingga kinerja menjadi rendah.

Hasil penelitian ini sejalan dengan (Adha, Qomariah \& Hafidz, 2019), (Budianto \& Katini, 2015), (Malik, 2015), (Putra, 2015), (Sidanti, 2015), (Runtunuwu, Lapian \& Dotulang, 2015). Hasil penelitiannya diperoleh bahwa lingkungan kerja berpengaruh dan signifikan baik secara parsial maupun secara simultan terhadap kinerja pegawai.

\section{Pengaruh Disiplin Kerja terhadap Kinerja Pegawai}

Berdasarkan hasil analisis terdapat pengaruh dan signifikan antara disiplin kerja terhadap kinerja pegawai pada Badan Kepegawaian dan Pengembangan Sumber Daya Manusia Daerah Kabupaten Kerinci. Hal ini dibuktikan dengan nilai $t$ hitung 4,973 lebih besar dari $\mathrm{t}$ tabel $(4,973>1,985)$ dengan tingkat signifikan lebih kecil dari alpha $(0,000<0,05)$, maka Ho ditolak dan $\mathrm{H}_{\mathrm{a}}$ diterima. Artinya, secara parsial ada pengaruh dan signifikan antara disiplin kerja $\left(\mathrm{X}_{3}\right)$ terhadap kinerja pegawai $(\mathrm{Y})$. Nilai koefisien regresi variabel disiplin kerja bernilai positif sebesar 0,336. Artinya bahwa setiap peningkatan disiplin kerja sebesar 1 satuan maka kinerja pegawai akan meningkat sebesar 0,336 satuan dengan asumsi variabel lain nilainya konstan.

Kedisiplinan adalah kunci keberhasilan suatu perusahaan dalam mencapai tujuannya. Kesadaran disini merupakan sikap seseorang yang secara sukarela menaati semua peraturan dan sadar akan tugas dan tanggung jawabnya. Jadi, dia akan mematuhi atau mengerjakan semua tugasnya dengan baik, bukan atas paksaan. Sedangkan kesediaan adalah suatu sikap, tingkah laku, dan perbuatan seseorang yang sesuai dengan peraturan instansi, baik yang tertulis maupun tidak tertulis.

Hasil penelitian ini sejalan dengan (Pratama \& Dihan, 2017), (Runtunuwu, Lapian \& Dotulang, 2015), (Sidanti, 2015). Hasil penelitiannya diperoleh bahwa disiplin kerja berpengaruh dan signifikan baik secara parsial maupun secara simultan terhadap kinerja pegawai.

\section{Pengaruh Komitmen Organisasi, Lingkungan Kerja dan Disiplin Kerja terhadap Kinerja Pegawai}


Berdasarkan hasil analisis dan uji hipotesis nilai $\mathrm{F}_{\text {-hitung }}$ sebesar 40,372 $>\mathrm{F}_{\text {-tabel }}$ sebesar 2,70, signifikansi probability $0,000<0,05$. Sehingga dapat disimpulkan bahwa nilai signifikansi kecil dari 0,05 , artinya signifikan, ini berarti komitmen organisasi, lingkungan kerja dan disiplin kerja secara bersama-sama berpengaruh dan signifikan terhadap kinerja pegawai. Kontribusi komitmen organisasi, lingkungan kerja dan disiplin kerja terhadap kinerja pegawai sebesar 55,7\% sedangkan sisanya $44,3 \%$ ditentukan oleh faktor lain. Faktorfaktor lain itu bisa berupa kompetensi, pemberdayaan, kepuasan kerja, pelatihan pegawai, pengembangan karier, kompetensi, budaya organisasi, gaya kepemimpinan, kompensasi dan lain sebagainya.

Jadi dapat disimpulkan bahwa komitmen organisasi, lingkungan kerja dan disiplin kerja yang baik dapat meningkatkan kinerja pegawai pada Badan Kepegawaian dan Pengembangan Sumber Daya Manusia Daerah Kabupaten Kerinci. Selain itu nilai konstanta yang didapat dari hasil analisis regresi linier berganda adalah 6,259, artinya jika segala sesuatu yang ada pada variabel-variabel independen dianggap konstan maka nilai dari kinerja pegawai adalah 6,259 .

Hasil penelitian ini sejalan dengan (Runtunuwu, Lapian \& Dotulang, 2015), (Sidanti, 2015), (Malik, 2015). Hasil penelitiannya diperoleh bahwa komitmen organisasi, lingkungan kerja dan disiplin kerja secara bersama-sama berpengaruh dan signifikan terhadap kinerja pegawai.

\section{KESIMPULAN}

Hasil penelitian ini menunjukkan bahwa komitmen organisasi berpengaruh dan signifikan terhadap kinerja pegawai, lingkungan kerja berpengaruh dan signifikan terhadap kinerja pegawai, disiplin kerja berpengaruh signifikan terhadap kinerja pegawai, komitmen organisasi, lingkungan kerja dan disiplin kerja secara bersama-sama berpengaruh dan signifikan terhadap kinerja pegawai BKPSDMD Kabupaten Kerinci.

\section{UCAPAN TERIMAKASIH}

Terima kasih kepada Universitas Putra Indonesia "YPTK" Padang yang telah memberikan kesempatan penulis untuk menyelesaiakan jurnal ini dan LPPM STIA Nusantara Sakti Sungai Penuh yang telah memberi kesempatan untuk publish jurnal di OJS Jurnal Administrasi Nusantara (JAN). Sertasemua pihak yang tidak bisa disebutkan satu persatu dalam jurnal ini

\section{DAFTAR RUJUKAN}

Adha, R.N., Qomariah, N., \& Hafidzi, A.H. (2019). Pengaruh Motivasi Kerja, Lingkungan Kerja, Budaya Kerja terhadap Kinerja Karyawan Dinas Sosial Kabupaten Jember. Jurnal Penelitian Ipteks, Vol 4 (1), 47-62.

Akbar, A., Musadieq, M.A., \& Mukzam, M.D. (2017). Pengaruh Komitmen Organisasional terhadap Kinerja (Studi pada Karyawan PT Pelindo Surabaya). Jurnal Administrasi Bisnis (JAB)Vol 47 (2), 33-38.

Algifari. (2011). Analisis Regresi untuk Bisnis dan Ekonomi. Edisi 3. Yogyakarta: Andi Baskoro, A.L., Widowati, S.Y., Santoso, A. (2019). Menakar Determinan Kinerja Karyawan. Jurnal Manajemen Bisnis dan Inovasi, Vol 6 (1), 41-50.

Budianto, A.A.T., \& Katini, A. (2015). Pengaruh Lingkungan Kerja terhadap Kinerja Pegawai pada PT Perusahaan Gas Negara (Persero) Tbk SBU Distribusi Wilayah Jakarta. Jurnal Ilmiah Prodi Manajemen Universitas Pamulang, Vol 3 (1), 100-124.

Edison. (2016). Manajemen Sumber Daya Manusia. Bandung: Alfabeta. 
Ghozali, I. (2017). Aplikasi Analisis Multivariete dengan Program IBM SPSS 23 (Edisi Ke8). Semarang: Badan Penerbit Universitas Diponegoro.

Ginanjar, M.S., Indarto., \& Santoso, D. (2019). Determinan Kinerja Pegawai dengan Motivasi sebagai Variabel Intervening. Jurnal Ekonomi, ISSN 2580-8451.

Hartatik, P.I. (2014). Buku Praktis Mengembangkan SDM. Yogyakarta: Suka Buku.

Hasibuan, M. (2016). Manajemen Sumber Daya Manusia. Jakarta: Bumi Aksara.

Kurniawan, A.H., Prasilowati, S.L., \& Suyanto. (2019). Determinan Kinerja Pegawai: Peran Beban Kerja, Motivasi dan Kepuasan Kerja. Jurnal Riset Manajemen dan Bisnis (JRBM) Fakultas Ekonomi UNIAT, Vol 4 (2), 287-294.

Malik, H.A. (2015). Analisis Kinerja Pegawai Melalui Komitmen Organisasional, Lingkungan Kerja dan Kepuasan Kerja Pegawai Pemerintah Kota Mataram. Jurnal Ilmu Ekonomi\& Manajemen, Vol 2 (1), 1-16.

Mangkunegara. (2016). Manajemen Sumber Daya Manusia. Bandung: PT Remaja Rosdakarya.

Mathis, L., \& Jackson, J. (2011). Human Resource Management. Jakarta: Salemba Empat.

Meilany, P., \& Ibrahim, M. (2015). Pengaruh Disiplin Kerja terhadap Kinerja Karyawan (Kasus Bagian Operasional PT. Indah Logistik Cargo Cabang Pekanbaru). JOM Fisip, Vol 2 (2), 1-11.

Mulyadi. (2015). Manajemen Sumber Daya Manusia. Bogor: Penerbit In Media.

Nawawi, H. (2016). Manajemen Sumber Daya Manusia. Yogyakarta: Gadjah Mada University Press.

Pattiasina, V. (2016). Determinan Kinerja Pegawai Sekretariat Daerah Kabupaten Jayapura. Jurnal Future, 151-171.

Pratama, A.P., \& Dihan, F.N. (2017). Pengaruh Komitmen Organisasional dan Disiplin Kerja terhadap Kinerja Karyawan Melalui Kepuasan Kerja sebagai Variabel Intervening. Jurnal Bisnis Teori dan Implementasi, Vol 8 (2), 115-135.

Prawirosentono. (2012). Manajemen Sumber Daya Manusia. Jakarta: Bumi Aksara.

Purnamawati, I.G.A., \& Yuniarta, G.A. (2017). Determinan Kinerja Karyawan: Studi pada Sektor Pariwisata di Kabupaten Buleleng. Jurnal Ilmu Sosial dan Humaniora, Vol 5 (2), 848-863.

Putra, S.W. (2015).Pengaruh Komitmen Organisasional, Budaya Organisasi, Gaya Kepemimpinan dan Lingkungan terhadap Kinerja Karyawan pada Industri Kecil. Modernisasi, Vol 11 (1), 62-77.

Respatiningsih, I., \& Sudirjo, F. (2015). Pengaruh Komitmen Organisasi, Motivasi, Kapabilitas dan Kepuasan Kerja terhadap Kinerja Pegawai (Studi Empirik pada Inspektorat Kabupaten Pemalang). Jurnal Ilmiah UNTAG Semarang, Vol 4 (3), 56-68.

Rivai, V. (2015). Manajemen Sumber Daya Manusia untuk Perusahaan: Dari Teori ke Praktik. Jakarta: Raja Grafindo Persada.

Robbin, S. (2015). Perilaku Organisasi. Jakarta: Salemba Empat.

Sapitri, R. (2016). Pengaruh Komitmen Organisasi terhadap Kinerja Karyawan Perusahaan Listrik Negara Area Pekanbaru. JOM Fisip, Vol 3 (2), 1-9.

Sarwoto. (2010). Dasar-Dasar Organisasi Manajemen. Jakarta: Ghalia.

Sedarmayanti. (2014). Sumber Daya Manusia dan Produktivitas Kerja. Bandung: Mandar Maju.

Sidanti, H. (2015). Pengaruh Lingkungan Kerja, Disiplin Kerja dan Motivasi Kerja terhadap

Kinerja Pegawai Negeri Sipil di Sekretariat DPRD Kabupaten Madiun. Jurnal JIBEKA, Vol 9 (1), 44-53. 
Sopiah. (2008). Perilaku Organisasi. Yogyakarta : Andi.

Sugiyono. (2014). Metode Penelitian Kuantitatif dan R\&D. Bandung: Alfabeta.

Suliyanto. (2011). Ekonometrika Terapan: Teori dan Aplikasi dengan SPSS. Yogyakarta: Penerbit Andi.

Sunarto. (2015). Manajemen Sumber Daya Manusia Strategik. Yogyakarta: Amus.

Sutrisno. (2016). Manajemen Sumber Daya Manusia. Jakarta: Pranada Media Group.

Umam, K. (2010). Perilaku Organisasi. Bandung: CV.Pustaka Setia.

Wibowo. 2016. Manajemen Kinerja, Edisi Kelima. Jakarta : PT Rajagrafindo Persada.

Wursanto. (2011). Dasar-Dasar Ilmu Organisasi. Yogyakarta: Andi. 